\title{
THE IMPLEMENTATION OF PROBLEM POSING APPROACH TO IMPROVE THE MATHEMATICAL CREATIVE THINKING ABILITIES OF JUNIOR HIGH SCHOOL
}

\author{
Neda Permana ${ }^{1)}$, Euis Eti Rohaeti ${ }^{2)}$, Ratni Purwasih ${ }^{3)}$ \\ ${ }^{1,2,3}$ IKIP Siliwangi, Kota Cimahi \\ Email: nedapermana@icloud.com
}

\begin{abstract}
The purpose of this study was to determine the increase in creative thinking skills of junior high school students who use learning by using the problem posing approach and the scientific approach to classroom learning, especially in mathematics. Quasi experiment is this type of research with the control group pre test and post test design. The research was conducted at one of the junior high schools in Cimahi City. As many as 62 students of class VII being sampled in this study consisted of 30 students in the experimental class with problem posing learning and 32 students in the control class with scientific learning. The testing in this study uses IBM SPSS version 22 software. The conclusions from the results of this study are 1) Increasing the ability of mathematical creative thinking by using a problem posing approach better than the scientific approach, 2) A problem posing approach if it is well planned for effectiveness when learning takes place, and 3) Students who are inaccurate in solving the problem of the ability to think creatively because they do not understand the problems asked in the questions. This can be seen from several responses of students who are incomplete in giving responses.
\end{abstract}

Keywords: Quasi Experiments, Mathematical Creative Thinking, Problem Posing, Scientific

\section{PENDAHULUAN}

Kemampuan berpikir kreatif matematik merupakan suatu aktivitas mental yang diantaranya meliputi keterampilan, kelancaran, berpikir luwes, keaslian, memperinci dan menilai serta memiliki empat indikator kemampuan diantaranya kepasihan (fluency), keluwesan (flexibility), keaslian (originality) dan keterincian (elaboration). Hal ini sejalan dengan Rahman, (2012) yang menjelaskan bahwa kemampuan berpikir kreatif matematik merupakan kemampuan dalam matematika yang meliputi empat indikator yaitu kelancaran, keluwesan, keaslian dan elaborasi.

Kemampuan berpikir kreatif merupakan salah satu hard skill di dalam matematik yang dimana siswa diharuskan memiliki dan mengembangakan kemampuan tersebut. Hal ini berbanding lurus dengan visi matematik yaitu pembelajaran matematik saat ini diharuskan mengarahka siswa untuk paham konsep dan idea matematik bukan hanya sekedar ingat tapi harus mampu untuk berpikir kreatif, logis kritis, menumbuhkan perilaku positif terhadap matematik, objektid dan terbuka, serta rasa ingin tahu dan senang belajar.

Namun pada kenyataannya, kemampuan berpikir kreatif di Indonesia masih belum berkembang dengan baik dan masih tergolong rendah. Hal ini sejalan dengan Fardah (Nasution, 2017) yang memaparkan bahwasanya kemampuan berpikir kreatif matematik siswa tergolong rendah dengan rincian siswa yang 
memiliki kemampuan berpikir kreatif tingkat tinggi sebanyak 20\% dari jumlah siswa, kategori sedang sebanyak 33,33\% serta kategori rendah sebanyak 46,7\%. Kemampuan berpikir kreatif matematik siswa yang lemah menyebabkan prestasi siswa tersebut rendah. Mengingat pentingnya kemampuan berpikir kreatif matematik maka perlu dicari alternatid pembelajaran yaitu dengan menerapkan pendekatan problem posing.

Problem posing merupakan pendekatan dalam pembelajaran yang dapat menggali kemampun matematika dengan cara diberikan sebuah permasalahan atau situasi, kemudian siswa dengan bebas diberikan kesempatan membuat pertanyaan dari permasalahan atau situasi tersebut. Hal ini sejalan dengan Kusumaningtyas, (2011) yang menjelaskan bahwa pendekatan problem posing merupakan suatu bentuk pendekatan dalam pembelajaran matematika yang menekankan pada perumusan soal yang dapat mengembangkan kemampuan berpikir kreatif matematik atau menggunakan pola pikir matematik.

Silver (Nugraha \& Mahmudi, 2015) mengkarifikasikan problem posing menjadi tiga jenis berdasarkan bentuk aktivitas kognitif yang berbeda yaitu (1) presolution posing yaitu siswa diharuskan membuat soal dari situasi atau permasalahan yang ada, (2) whitin-solution posing yaitu siswa diharuskan merumuskan ulang soal seperti yang diselesaikan dan (3) post-solution posing yaitu siswa diharuskan memodifikasi tujuan atau kondisi soal yang telah diselesaikan untuk membuat soal baru. Berdasarkan paparan diatas maka terlihat pendekatan problem posing memiliki pengaruh terhadap kemampuan berpikir kreatif matematik siswa.

\section{METODE PENELITIAN}

Penelitian ini merupakan penelitian Quasi Experimental dengan desain penelitian Control Group Pre-test and Post-test. Populasi dari penelitian ini merupakan siswa kelas VII. Sampel dalam penelitian ini terdiri dari 62 siswa dimana 30 siswa menjadi bagian dari kelas eksperimen dan 32 siswa menjadi kelas kontrol. Adapun desain menurut Russeffendi (Aripin \& Purwasih, 2017) sebagai berikut :

$\begin{array}{lllll}\text { A } & \mathrm{O} & \mathrm{X} & \mathrm{O} & \text { Kelas Eksperimen } \\ \mathrm{A} & \mathrm{O} & & \mathrm{O} & \text { Kelas Kontrol }\end{array}$

Keterangan :

$\mathrm{A}=$ Acak kelas

$\mathrm{O}=$ Pre-test $=$ Post-test $($ tes kemampuan berpikir kreatif matematik)

$\mathrm{X}=$ Pembelajaran dengan menggunakan pendekatan problem posing

Instrumen tes yang digunakan dalam penelitian ini berupa 5 soal uraian yang mengandung indikator kemampuan berpikir kreatif matematik. Pengolahan data dilakukan menggunakan bantuan Software IBM SPSS 22.

Adapun untuk mengetahui seberapa besar penumbuhan kemampuan berpikir kreatif matematik siswa sebelum diberikan perlakuan dan setelah diberikan perlakuan, maka perlu dihitung menggunakan gain ternormaliasi. Menurut Hake (Waldrip, 2014) data gain dapat dihitung dengan rumus sebagai berikut : 


$$
g=\frac{\text { posttest }- \text { pretest }}{\text { maximum score }- \text { pretest }}
$$

\section{HASIL PENELITIAN DAN PEMBAHASAN}

Sebelum dilakukan perlakuan disetiap kelas baik eksperimen ataupun kontrol terlebih dahulu diberikan sebuah tes awal (pre-test) yang memiliki tujuan yaitu untuk mengukur kemampuan awal berpikir kreatif matematik siswa. Setelah tes awal diberikan kemudian dilakukan perlakukan dengan ketentuan kelas eksperimen menggunakan pendekatan problem posing dalam proses belajar, sedangkan kelas kontrol menggunakan pembelajaran menggunakan pendekatan scientific. Kemudian dilakukan tes akhir (post-test) untuk mengukur kemampuan berpikir kreatif matematik siswa baik kelas eksperimen atau kontrol. Selanjutnya adalah menganalisis data hasil pre-test, post-test kemampuan berpikir kreatif matematik. Adapun data hasil analisis yang disajikan dalam Tabel 1 sebagai berikut :

Tabel 1. Statistik Deskriptif Hasil Tes Kemampuan Berpikir Kreatif Matematik

\begin{tabular}{cccccccc}
\hline \multirow{2}{*}{ Kemampuan } & \multicolumn{3}{c}{ Kelas Eksperimen } & \multicolumn{3}{c}{ Kelas Kontrol } \\
& & Pre-test & $\begin{array}{c}\text { Post- } \\
\text { test }\end{array}$ & Gain & Pre-test & $\begin{array}{c}\text { Post- } \\
\text { test }\end{array}$ & Gain \\
\cline { 3 - 8 } Berpikir & $\bar{x}$ & 1,70 & 11,37 & 0,53 & 1,81 & 4,87 & 0,17 \\
Kreatif & $\mathrm{S}$ & 2,10 & 3,96 & 0,19 & 1,94 & 3,29 & 0,16 \\
\hline
\end{tabular}

Dalam Tabel 1 terlihat bahwa gain kelas eksperimen dan kelas kontrol memiliki selisih sebesar 0.36 , itu berarti terdapat perbedaan yang signifikan dari kelas eksperimen dan kelas kontrol. Langkah selanjutnya adalah melakukan pengujian terhadap data gain post-test. Pengujian menggunakan Software IBM SPSS versi 22, adapun hipotesis yang digunakan dalam pengujian tersebut sebagai berikut :

$H_{0}: \mu_{1} \leq \mu_{2}$, peningkatan kemampuan berpikir kreatif matematik dengan menggunakan pendekatan problem posing kurang dari atau sama dengan pendekatan scientific secara signifikan.

$H_{1}: \mu_{1}>\mu_{2}$, peningkatan kemampuan berpikir kreatif matematik dengan menggunakan pendekatan problem posing lebih baik dari pendekatan scientific secara signifikan.

Selain hipotesis tedapat pula kriteria pengujian yang digunakan dalam pengujian tersebut yaitu:

Jika Sig. $>0.05$ terima $H_{0}$

Jika Sig. $\leq 0.05$ terima $H_{1}$

Adapun hasil pengujian data gain yang disajikan dalam Tabel 2 sebagai berikut: 
Tabel 2. Hasil Uji-T Data Gain

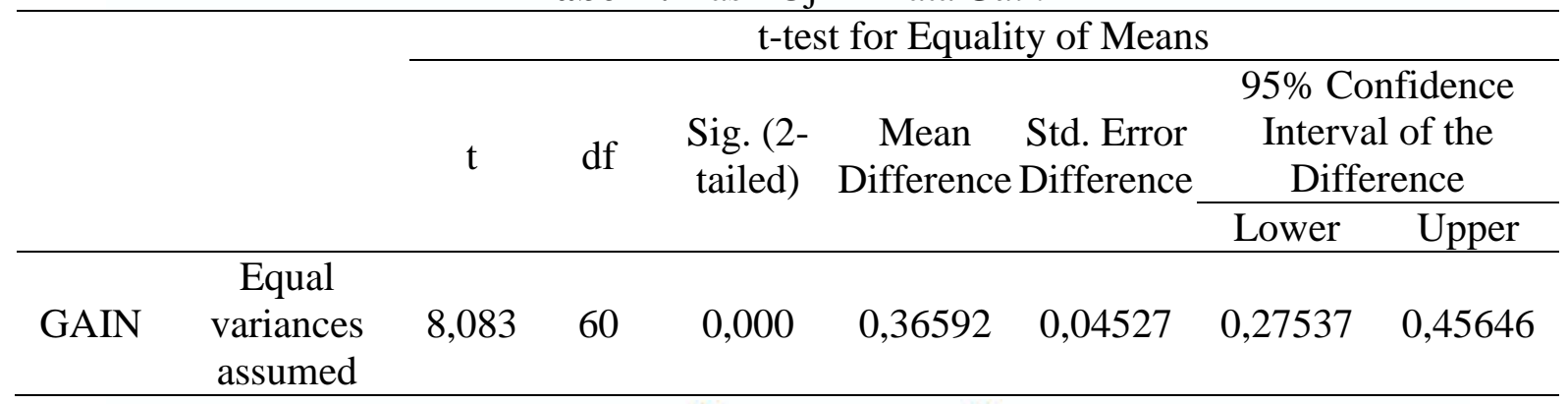

Karena sig $<0.05$ maka $H_{0}$ ditolak dan $H_{1}$ diterima, itu berarti dapat disimpulkan bahwasanya pertumbuhan kemampuan berpikir kreatif matematik dengan menggunakan pendekatan problem posing lebih baik dari pendekatan scientific secara signifikan.

Berdasarkan normalized gain Hake (Ariesta, 2011) terdapat perbedaan kualifikasi antara kelas eksperimen dan kelas kontrol, dimana n-gain kemampuan berpikir kreatif matematik dari rata-rata post-test kelas eksperimen sebesar 0,53 yang berarti sedang dan kelas eksperimen 0,17 yang berarti rendah.

Dalam penelitian ini terdapat tujuan yaitu untuk mengetahui peningkatan kemampuan berpikir kreatif siswa SMP yang menggunakan pembelajaran dengan menggunakan pendekatan problem posing dan pendekatan scientific terhadap pembelajaran di kelas khususnya pada pelajaran matematika. Dari hasil uji-t data gain disimpulkan bahwasanya pertumbuhan kemampuan berpikir kreatif matematik dengan menggunakan pendekatan problem posing lebih baik dari pendekatan scientific secara signifikan.

Dalam mewujudkan tujuan tersebut perlu adanya penerapan pendekatanpendekatan yang di gunakan dalam penelitian ini khususnya pendekatan problem posing dan pendekatan scientific.

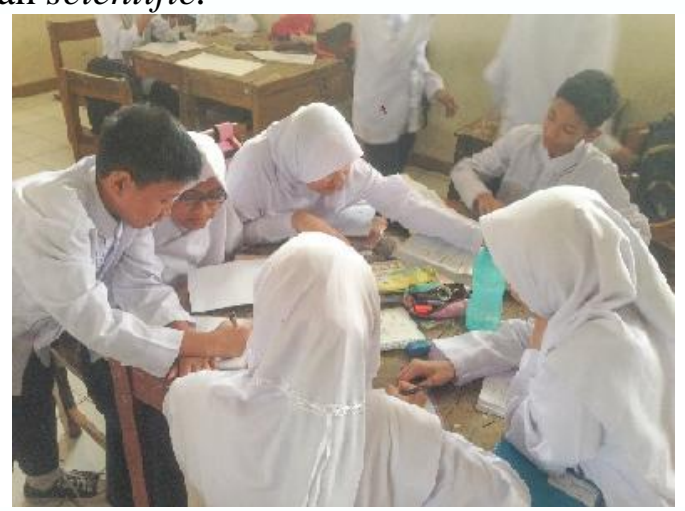

Gambar 1. Aktivitas Siswa Kelas Ekperimen

Dalam penerapan pendekatan problem posing terdapat beberapa tahapan dalam pembelajaran. Pada tahap persiapan dimana guru menyampaikan tujuan pembelajaran serta menggali pengetahuan awal siswa tentang materi aritmatika sosial serta membagi siswa menjadi beberapa kelompok dimana satu kelompok terdiri dari 4-5 siswa. Pada tahap kedua guru memberikan penjelasan kepada siswa tentang materi aritmatika sosial yang akan dipelajari secara singkat. Tahap ketiga guru memberikan LKS pendekatan problem posing dimana dalam LKS 
terdapat beberapa situasi atau masalah yang dapat memacu siswa untuk mengembangkannya menjadi beberapa pertanyaan yang memungkinkan serta siswa diharuskan memberikan jawaban atas pertanyaan yang dibuatnya. Tahap keempat guru melakukan verifikasi dimana guru melakukan pengecekan terhadap pemahan siswa terhadap materi aritmatika sosial dengan cara meminta siswa mempresentasikan soal atau pertanyaan yang telah dibuat secara berkelompok. Langkah-langkah problem posing tersebut sejalan dengan Ngaeni \& Saefudin, (2017) yang menjelaskan bahwa langkah-langkah pembelajara problem posing adalah sebagai berikut: (1) Guru menjelaskan materi pelajaran, (2) Siswa diminta mengajukan soal yang menantang serta dapat menyelesaikannya dengan cara dilakukan bersama kelompok, (3) Guru menyuruh siswa menyajikan soal temuannya di depan kelas.

Langkah-langkah pembelajaran tersebut membuat pembelajaran menjadi lebih efektif dan tidak monoton.

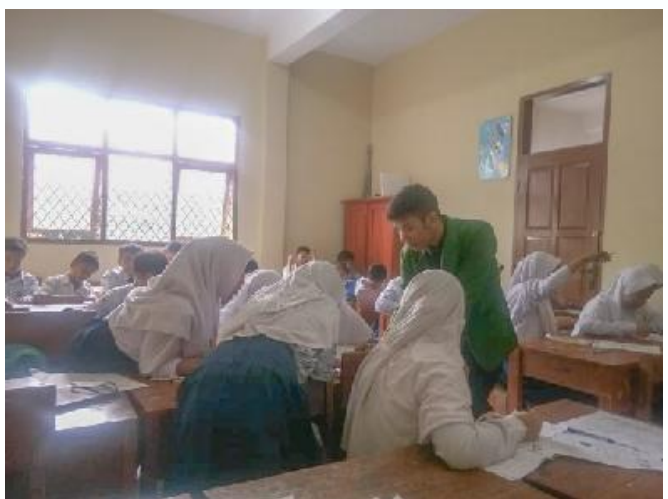

Gambar 2. Aktivitas Siswa Kelas Kontrol

Sedangkan pada kelas kontrol pada tahapan pertama guru melakukan pembukaan pembelajaran, membagi siswa menjadi beberapa kelompok dimana satu kelompok terdiri dari 4-5 siswa serta memberikan gambaran tentang manfaat yang diperoleh siswa saat mempelajari materi aritmatika sosial. Pada tahap kedua guru memberikan LKS kemudian LKS tersebut diamati oleh siswa. Pada tahap ketiga siswa diberikan kesempatan untuk bertanya terkait permasalahan yang terdapat pada LKS. Pada tahap keempat guru memberikan kesempatan kepada siswa untuk mencoba memberikan jawaban. Pada tahap kelima guru menginstruksikan kepada siswa untuk mencoba menyelesaikan permasalahan lain yang ada dalam LKS dan pada tahap terakhir perwakilan siswa dalam tiap kelompok diminta untuk memaparkan hasil diskusi kelompoknya didepan kelas.

Selain penerapan pendekatan perlu dianalisis bagaimana respon siswa terhadap 5 soal uraian yang memuat indikator kemampuan berpikir kreatif matematik. Dalam analisis respon siswa terhadap soal, data yang digunakan berupa lembar jawaban siswa dengan sampel sebanyak satu orang. Tujuan dari analisis respon siswa terhadap soal adalah untuk mengetahui kesalahan-kesalahan siswa dalam menjawab atau memberikan respon terhadap soal yang diberikan. 
Lembar jawaban yang dianalisis merupakan lembar jawaban tes akhir (post-test) kemampuan berpikir kreatif matematik.

Pada butir soal pertama indikator yang dinilai adalah kepasihan (fluency) dimana siswa diharuskan dapat mencetuskan banyak ide dengan lancar.

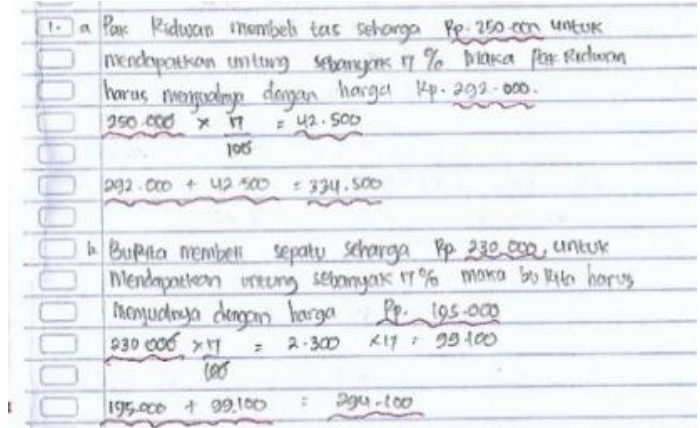

Gambar 3. Respon siswa terhadap soal nomor 1

Pada respon siswa diatas siswa terlihat sudah mampu dalam memberikan lebih dari satu ide yang relevan hanya terjadi kekeliruan dalam menghitung harga jual. Dalam ide yang pertama, jika harga sebuah tas Rp.250.000 maka untuk mendapatkan untung sebanyak $17 \%$ maka harga jual tas tersebut seharusnya $\mathrm{Rp}$. 292.500. Selain itu dalam perhitungan siswa terlihat kebingungan dalam menentukan harga jual. Terlihat siswa sudah mampu menghitung jumlah $17 \%$ dari Rp. 250.000 tetapi dalam penjumlahan untuk mencari harga jual, siswa menjumlahkan keuntungan dan harga jual Rp. 292.000.

Untuk ide kedua, tertuliskan harga sepatu Rp.230.000 kemudian siswa masih keliru dalam menghitung harga jual yang menghasilkan keuntungan sebesar $17 \%$. Terlihat dari siswa yang menuliskan Rp. 195.000 untuk harga jual sedangkan harga jual yang mengalami keuntungan pasti akan lebih besar dari pada harga beli. Jadi dapat disimpulkan untuk ide pertama dan kedua siswa masih kebingungan dalam menentukan harga jual yang mendapat untung $17 \%$.

Pada butir soal kedua indikator yang dinilai adalah keaslian (originality) dimana siswa diharuskan menggunakan caranya sendiri dalam menyelesaikan masalah dengan orisinil/asli dan hasil yang benar.

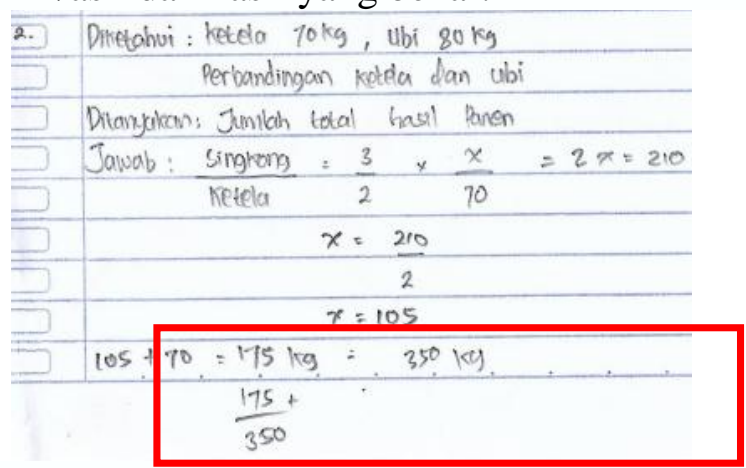

Gambar 4. Respon siswa terhadap soal nomor 2

Dalam respon siswa diatas terlihat siswa sudah dapat memberi jawaban dengan caranya sendiri dengan proses perhitungan yang benar, tetapi akan lebih baik jika hasil perhitungan yang ditandai dengan kotak merah dilengkapi menjadi 


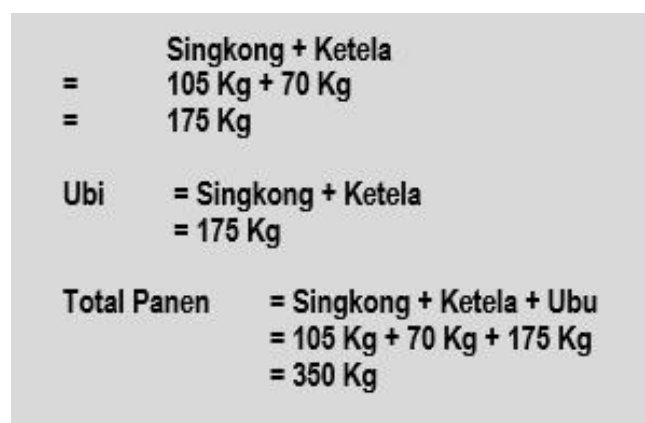

Gambar 5. Jawaban yang diharapkan

Akan tetapi siswa tersebut sudah memberikan jawaban menggunakan caranya sendiri, maka dapat disimpulkan jika siswa sudah memahami soal yang diberikan serta menunjukkan kemampuannya dalam menyelesaikan soal kemampuan berpikir kreatif matematik dengan indikator keaslian (originality)

Pada butir soal ketiga indikator yang dinilai adalah keluwesan (flexibility) dimana siswa diharuskan menggunakan beragaman strategi dan cara penyelesaian masalah. Pada respon siswa nomor 3 terlihat siswa sudah mampu menyelesaikan soal dengan benar, akan tetapi karena dalam soal nomor 3 merupakan indikator keluwesan (flexibility) dimana keberagaman strategi serta cara penyelesaian masalah dituntut maka skor yang diberikan tidak maksimal karena mengacu pada rubrik penilaian.

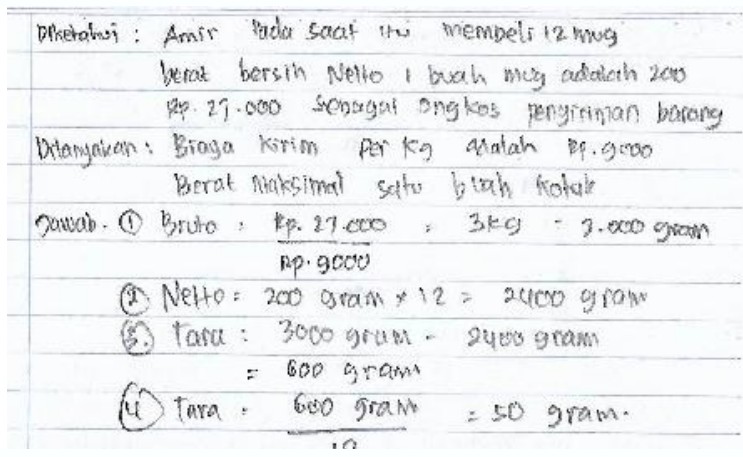

Gambar 6. Respon siswa terhadap soal nomor 3

Dalam kasus tersebut siswa memberikan jawaban dengan satu cara tetapi proses perhitungan dan hasilnya benar.

Pada butir soal keempat dan kelima indikator yang dinilai adalah rinci (elaboration) dimana siswa diharuskan memberikan penjelasan yang rinci terhadap penyelesaian suatu masalah. 


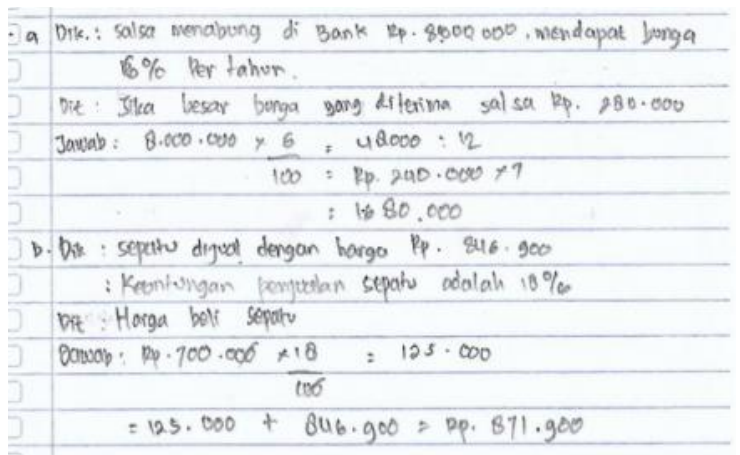

Gambar 7. Respon siswa terhadap soal nomor 4

Pada respon siswa terhadap soal nomor 4 terdapat kesalaan jawaban tetapi disertai perincian yang kurang detail. Terlihat dalam penyelesaiannya siswa sudah mampu merinci tetapi kurang detail dan masih kurang tepat, terlihat dalam nomor 4 bagian a pada saat merinci apa saja yang diketahui dari soal siswa kurang lengkap dalam melakukan perincian. Kemudian pada bagian yang ditanyakan siswa pun kurang tepat dalam menjawabnya. Pada hasil jawaban seharusnya siswa memerinci dengan jelas, adapun jawaban yang diharapkan sebagai berikut :

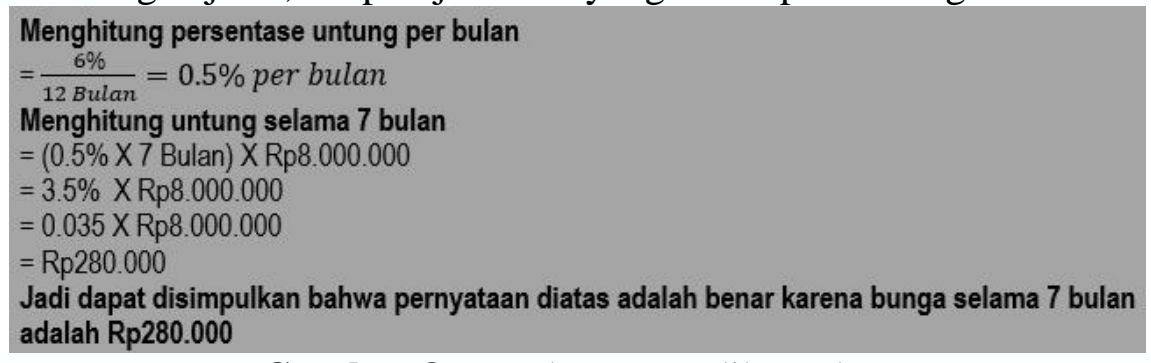

Gambar 8. Jawaban yang diharapkan

Pada jawaban siswa nomor 4 bagian $b$ terlihat masih tidak berbeda dengan jawaban siswa nomor 4 bagian a hanya saja pada bagian b siswa sudah mampu membedakan mana yang diketahui dan mana yang ditanyakan.

Pada respon siswa terhadap soal nomor 5 terdapat kesalaan jawaban tetapi disertai perincian yang kurang detail. Terlihat dalam penyelesaiannya siswa sudah mampu merinci tetapi kurang detail dan masih kurang tepat. Kemudian dalam perhitungan siswa pun masih kurang tepat.

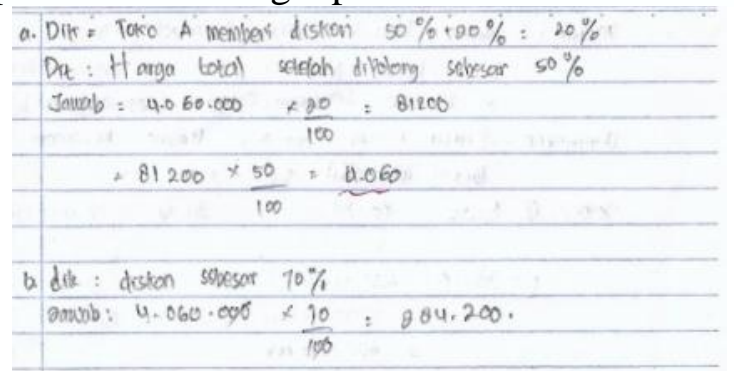

Gambar 9. Respon siswa terhadap soal nomor 5 Adapun jawaban yang diharapkan sebagai berikut : 


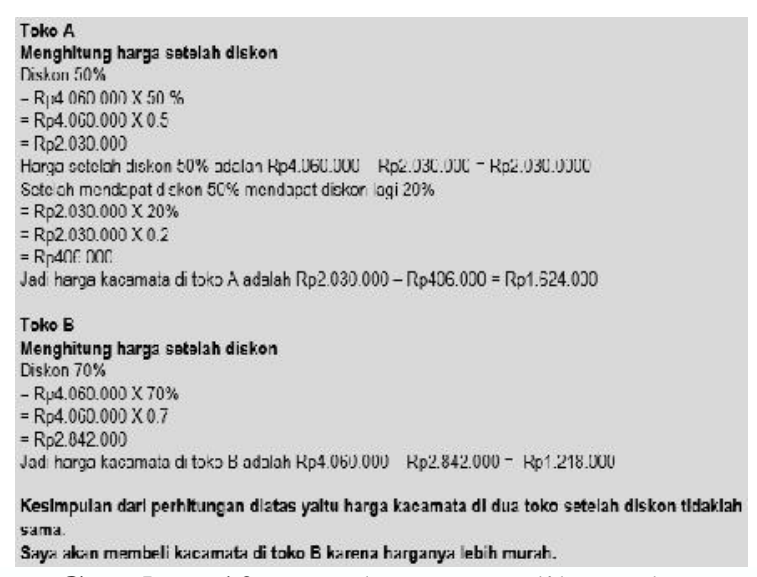

Gambar 10. Jawaban yang diharapkan

Dalam analisis respon siswa terhadap soal diperlukan kemampuan berpikir kreatif matematik yang diantaranya siswa harus mampu dalam (1) mencetuskan banyak ide dengan lancar; (2) menggunakan caranya sendiri dalam menyelesaikan masalah dengan orisinil/asli dengan hasil yang benar; (3) menggunakan beragam strategi dan cara penyelesaian masalah; dan (4) memberikan penjelasan yang rinci terhadap penyelesaian masalah. Hal ini sesuai dengan definisi kemampuan berpikir kreatif matematik oleh Munandan menurut Balka, Mann (Hendriana, Heris; Rohaeti, Euis Eti; Sumarmo, 2017) yang merinci kemampuan berpikir kreatif matematik menjadi (1) merupakan kemampuan untuk memformulasikan hipotesis matematka yang memfokuskan pada sebab dan akibat dari suatu masalah; (2) kemampuan yang menentukan pola-pola yang terdapat didalam situasi-situasi masalah matematik; (3) kemampuan memecahkan masalah dengan mengajukan solusi-solusi baru dari masalah-masalah matematik; (4) kemampuan menentukan ide yang tidak biasa dan dapat mengevaluasi konsekuensi yang ditimbulkan; (5) kemampuan mengidentifikasi informasi matematik yang hilang dari masalah yang diberikan; dan (6) kemampuan merinci masalah matematik yang umum ke dalam sub-sub masalah yang lebih spesifik.

\section{SIMPULAN DAN SARAN Simpulan}

Berdasarkan hasil analisis data dan pembehasan diatas, maka dapat disimpulkan bahwa : (1) Peningkatan kemampuan berpikir kreatif matematik dengan menggunakan pendekatan problem posing lebih baik dari pendekatan scientific, (2) Pendekatan problem posing jika dilakukan secara terencana dengan baik akan keefektifan pada saat pembelajaran berlangsung, dan (3) Siswa yang kurang tepat dalam melakukan penyelesaian soal kemampuan berpikir kreatif karena kurang memahami permasalahan yang ditanyakan di dalam soal. Hal ini terlihat dari beberapa respon siswa yang kurang lengkap dalam memberikan respon. 


\section{Saran}

Adapun saran yang didasarkan temuan dalam penelitian ini adalah sebagai berikut : (1) Bagi Siswa, hendaknya siswa lebih mengasah kemampuan berpikir kreatif serta berpikiran postif pada matematika, (2) Bagi Guru, dapat menggunakan pendekatan problem posing atau mencari pendekatan-pendekatan lain yang digunakan dalam pembelajaran untuk mengembangkan kemampuan berpikir kreatif siswa.

\section{DAFTAR PUSTAKA}

Ariesta, R. (2011). Pengembangan perangkat perkuliahan kegiatan laboratorium fisika dasar II berbasis inkuiri terbimbing untuk meningkatkan kerja ilmiah mahasiswa. Jurnal Pendidikan Fisika Indonesia, 7(1).

Aripin, U., \& Purwasih, R. (2017). Penerapan Pembelajaran Berbasis Alternative Solutions Worksheet Untuk Meningkatkan Kemampuan Berpikir Kreatif. Jurnal Aksioma, 6(2), 225-233.

Hendriana, Heris; Rohaeti, Euis Eti; Sumarmo, U. (2017). Hard Skills dan Soft Skills Matematik Siswa. Bandung.

Kusumaningtyas, I. H. (2011). Upaya Meningkatkan Pemahaman Konsep Matematika Melalui Pendekatan Problem Posing dengan Pembelajaran Kooperatif Tipe STAD (Student Teams Achievement Divisions) pada Siswa kelas Bilingual VIII C SMP N 1 Wonosari. Skripsi Pada Universitas Negeri Yogyakarta. Yogyakarta. Tidak Diterbitkan.

Nasution, P. R. (2017). Perbedaan Peningkatan Kemampuan Berpikir Kreatif Matematis dan Kemandirian Belajar Siswa pada Pembelajaran Berbasis Masalah dan Pembelajaran Konvensional di SMPN 4 Padangsidimpuan. Jurnal Paidagogeo, 2(1), 46-62.

Ngaeni, E. N., \& Saefudin, A. A. (2017). Menciptakan Pembelajaran Matematika yang Efektif Dalam Pemecahan Masalah Matematika Dengan Model pembelajaran Problem posing. Jurnal Aksioma, 6(2), 264-274.

Nugraha, T. S., \& Mahmudi, A. (2015). Keefektifan pembelajaran berbasis masalah dan problem posing ditinjau dari kemampuan berpikir logis dan kritis. Jurnal Riset Pendidikan Matematika, 2(1), 107-120.

Rahman, R. (2012). Hubungan Antara Self-Concept Terhadap Matematika dengan Kemampuan Berpikir Kreatif Matematik Siswa. Infinity Journal, 1(1), 19_ 30 